\title{
Operation “Artemis": The First Autonomous EU-led Operation
}

\author{
TOMOLYA János ${ }^{1}$
}

\begin{abstract}
In June 2003, the EU launched Operation “Artemis”, its first military mission outside Europe and independent of NATO, to the Democratic Republic of Congo. While it ultimately received an EU badge, its origin, command and control were French. The objective of Operation "Artemis" was to contribute to the stabilisation of the security conditions in Bunia, capital of Ituri, to improve the humanitarian situation, and to ensure the protection of displaced persons in the refugee camps in Bunia. Its mandate was to provide a short-term interim force for three months until the transition to the reinforced United Nations Mission in the Democratic Republic of Congo (MONUC - Mission de l'Organisation des Nations Unies en République Démocratique du Congo; English: United Nations Organization Stabilization Mission in the Democratic Republic of the Congo). Although the EU can be said to have passed the first "test" of the European Security and Defence Policy (ESDP) mechanisms for the conduct of an autonomous operation, this test was a limited one. Operational constraints were caused by inadequate strategic lift capabilities and the lack of a strategic reserve.
\end{abstract}

Keywords: Democratic Republic of Congo, Ituri, Bunia, MONUC, poor governance, inefficient state, civil war, rebels, anti-rebels, humanitarian crisis

\section{Introduction}

The Ituri region is often described as the bloodiest corner of the Democratic Republic of Congo (DRC). Despite three peace agreements purportedly ending the five-year old Congolese war, fighting in northeastern DRC intensified in late 2002 and early 2003. In early May 2003, hundreds of civilians were slaughtered in the town of Bunia and tens of thousands of others were forced to flee. [1] Some, desperately looking for protection from the violence, sought shelter near the United Nations compound. While the international community focused on the town of Bunia, massacres continued in other parts of Ituri away from media attention. As one witness described it, "Ituri was covered in blood” because of the lack of state efficiency and due to an absence of effective government control. [2]

Based on information gathered by its researchers and on other reports, Human Rights Watch estimates that at least 5,000 civilians died from direct violence in Ituri between July 2002 and March 2003. These victims are in addition to the 50,000 civilians that the United Nations estimates have died there since 1999. These losses are just part of an estimated total of 3.3 million civilian dead throughout the Congo, a toll that makes this war more deadly to civilians than any other since World War II. [3]

1 The author (a Colonel of the Hungarian Defence Force), conseiller of EUSEC RD Congo, and served as Chief of J1 in Operation ARTEMIS’s OHQ. E-mail: tomolyaj@hotmail.com 
Armed groups have committed war crimes, crimes against humanity, and other violations of international humanitarian and human rights law on a massive scale in Ituri. Assailants have massacred unarmed civilians, often solely on the basis of their ethnicity, killing scores and sometimes hundreds of civilians in each such attack. In one of several such massacres documented by Human Rights Watch researchers, Ngiti combatants together with soldiers of the Congolese Popular Army (Armée Populaire Congolaise, APC) of Mbusa Nyamwisi killed at least 1,200 Hema and Bira children, women and other civilians in Nyakunde. Over a ten-day period assailants carried out a well-planned operation, systematically slaughtering and often torturing civilians in house-to-house searches and executing hospital patients still in their beds. Many other massacres, especially those that occurred in more remote areas, were never even reported.

Armed groups also committed summary executions, forcefully abducted persons whose whereabouts remain unknown, and arbitrarily arrested and unlawfully detained others, some of whom they subjected to systematic torture. Survivors told Human Rights Watch researchers that the Hema Union of Congolese Patriots (UPC) conducted a "man hunt" for Lendu and other political opponents shortly after taking power in August 2002. Many Lendus were arrested. Others fled or went into hiding, afraid to walk openly in the streets of Bunia. According to witnesses, senior UPC military officers were in charge of two prison areas that became notorious places of summary execution and torture. Combatants of armed groups also committed rapes and engaged in such inhumane acts as mutilation and cannibalism, a practice meant to bring ritual strength to perpetrators and to inspire terror in opponents.

This essays attempts to critically assess the efficacy of Operation "Artemis”, a peacekeeping mission of the European Union in the Democratic Republic of Congo (DRC). This mission, initiated just a few months after the beginning of the Iraq war in 2003, was the response of the European Union to the Civil war in the DRC, which could not be controlled by international peacekeepers. Operation “Artemis” was the very first EU-led peacekeeping force in combat and attempted to restore order and peace in the Ituri province for a mandate of three months.

In the first part, I will focus on the mission itself. Firstly, the background of the concerned area and the mission will be explained, including the challenges that led the United Nations Security Council to delegate this mandate to Operation "Artemis". Secondly, this essay will also investigate why the European Union accepted the responsibility of this mandate. The tasks of this mandate will be described thereafter. This is followed by the diplomatic and military preparations of the mission. Finally, the actual development of the mission will be described and what results it gathered. In the second part, the mission will be evaluated according to its individual strengths and weaknesses, including the overall assessment. Achievements of the mission will be complemented with recommendations for future missions.

In evaluating this mission, especially in the context of the Iraq War, it will also assess in a broader context if the European Union is able to be an effective international player. This essay concludes that Operation "Artemis" illustrates that the EU has the capabilities to successfully execute mandates, if the EU member states are willing and agree upon foreign policy actions. 


\section{Background of the Ituri Conflict}

The region of Ituri is a district of the vast Orientale Province. It has a population of about 4.5 million, according to aid agencies working there. Figures of the make-up of the population differ widely. The town of Bunia, swelled by displaced families, is thought to hold at least 300,000 people. The main ethnic groups are the Alur, Hema, Lendu, Ngiti, Bira and Ndo-Okebo. On the key question of the relative size of these communities, there are conflicting figures. The Alur are often regarded as the largest community in the region, but some figures indicate the Lendu are the largest group. The comparative size of the Hema and Lendu is unclear.

There are other, smaller ethnic groups indigenous to the region, including the Twa and a wide diversity of groups from other regions, particularly in the towns. Generally speaking, the Hema are associated with animal husbandry and business, and the Lendu with agriculture. A key Lendu grievance is a perception of unjust accumulation of land in Hema hands, inasmuch as Belgian colonial administrators favoured the Hema at independence with large land concessions. As the conflict escalated, Hema leaders, on their side, have expressed fears of being targeted for "ethnic cleansing” or even genocide. In the ethnic ideology which has poisoned the Great Lakes region, the two are sometimes seen (however inaccurately) as representing two sides of a Bantu-Nilotic clash. Clashes between Hema and Lendu over land ownership and rights over land for grazing have broken out on several occasions in the last three decades. However, the deadliest phase of the tensions between the two communities started in May 1999. Each group attempted to expel the other from contested areas in a policy of local "ethnic cleansing”.

The 1994 Genocide of Tutsis in Rwanda led to a civil war, which resulted in Hutu refugees, fearing revenge of Tutsis, crossing into Zaire. The counterattack of Hutu forces into Rwanda from Zaire in turn resulted in the Rwandan invasion of Zaire. This led to the First Congo War, during which Zairean opposition leader Kabila, with Ugandan and Rwandan military support, replaced Mobutu as head of Zaire in 1997. Zaire was renamed the "Democratic Republic of Congo” (DRC). Shortly thereafter, the Second Congo War broke out, when Kabila refused his former allies Uganda and Rwanda the spoils of the First Congo War. Their invasion into the Eastern DRC prompted invasions by Angola, Namibia and Zimbabwe in 1998 on behalf of Kabila's government.

In the absence of national authority, good and efficient governance (whose criteria have been described by Maria Bordas) mass killings, rape, torture, displacement, mutilation and cannibalism took place in Ituri. These were brought to the attention of the international community by the United Nations and non-governmental organizations. [4]

In 1999, the UN Security Council authorized 90 peacekeepers to assist in promoting the Lusaka peace agreement that had been reached by the six involved countries, and provided for an interim authority to be established in Ituri. [5] Yet violence continued and the peace agreement was widely disregarded, while fighting and massacres continued. Following the six-day war between Rwanda and Uganda, in 2000 the United Nations Security Council (UNSC) Resolution 1291 approved deployment, under Chapter VII of the UN Charter, sending 5,537 peacekeepers from the United Nations into Congo, called MONUC to monitor the implementation of the ceasefire. [6] 
When MONUC deployed its first contingent in a very limited manner with one senior political advisor, one political officer, one civil affairs officer and one humanitarian officer to the rebel-held East in 2001, finally an accord was signed between Presidents Kabila and Kagame of Rwanda in 2002 to withdraw Rwandan troops from the DRC, once Rwanda's security concerns were addressed. This was followed in October 2002 by the withdrawal of Angolan, Namibian and Zimbabwean troops that had supported the DRC government.

The European Union had previously called for a resolution to end the violence in Ituri in December 2002. The Security Council demanded firmly the withdrawal of Ugandan forces from Ituri. Uganda agreed in 2003, and withdrew its forces in a chaotic fashion in May 2003. This security vacuum was not filled and the Lendu and Hema tribal militias started fighting each other in Ituri's regional capital, Bunia, over control of land and resources, which resulted in a humanitarian disaster. United Nations investigators reported massacres from February 2003; at the same time some 500,000 to 600,000 people were displaced throughout the region. [7]

The humanitarian conditions deteriorated rapidly, and the violence resulted in the creation of approximately 7,000 refugees. [8] The streets beyond the UN compounds fell under the control of rival militias, whose violent attacks on each other's civilians made any kind of humanitarian and other assistance to the population in need impossible. Bunia was plagued by rival militiamen openly carrying small arms. The situation was exacerbated by the fact that a number of military, political and logistical difficulties were amplified by the inadequate resources such as low troop ceilings. For instance, at the time of the 2003 Ituri crisis, MONUC's troop strength was under half of its authorized level. The 700 UN peacekeepers, mostly from Uruguay, who were deployed on April 23 $3^{\text {rd }}$ near Bunia, did not have the mandate necessary to prevent the violence. They could only protect UN personnel and lacked the capacity to do much more. Bunia was overrun by violence, while MONUC headquarters and personnel were directly attacked. In an attempt to escape the ensuing violence, thousands of civilians either abandoned the town or collected around MONUC sector 2 Headquarters and the airport where the Uruguayan battalion had established its base.

\section{Way to Operation “Artemis"}

Since the deployment of a better equipped and mandated MONUC force was not possible before the end of July 2003, it left a dangerous interim gap in this highly volatile area. The Secretary-General addressed a letter to the President of the Security Council on the $15^{\text {th }}$ May, 2003. In his letter the Secretary-General called for the rapid deployment to Bunia of a highly trained and well-equipped multinational force, under the lead of a Member State, to provide security at the airport as well as to other vital installations in the town and to protect the civilian population.

UN General Secretary Kofi Annan specifically appealed to Javier Solana to build support among EU defence ministers. Solana, as former NATO General Secretary, then Spanish Foreign minister and president of the European Council of Ministers, was in a good position to promote collective values and shared norms regarding the EU's strategic interests in Africa. At a meeting of the EU defence ministers in May 2003, Solana presented Annan's request on May $19^{\text {th }}$ to the meeting of EU defence ministers and drafted a response to Annan from the EU, while he sent his assistant, Aldo Ajello, to initiate diplomatic overtures with Uganda, Rwanda, and the DRC to withdraw, while briefing the UN Security Council. Following a 
call to President Jacques Chirac by the Secretary-General, France indicated its readiness to deploy a force to Bunia. On 30 May, 2003, the Security Council authorized the deployment.

The assassination of two UN military observers on $30^{\text {th }}$ May, 2003 made the situation in Bunia spiral out of control and the plight of the civilians who sought refuge around the MONUC compound and the airport eventually led to the deployment of the IEMF (Interim Emergency Multinational Force) under the leadership of France. On the $30^{\text {th }}$ May, 2003, UN SC Resolution 1484 authorized a mandate for the deployment of an emergency international force (Interim Emergency Multinational Force in Bunia), until 1 September, 2003. The international force was to contribute to the stabilisation of the security conditions and the improvement of the humanitarian situation in Bunia, by ensuring the protection of the airport and internally displaced refugees in the camps in Bunia, and if required, of the civilian population, United Nations personnel and of humanitarian agencies in the town.

France declared it willingness and readiness to deploy a French-led Interim Emergency Multinational Force, known as Operation “Artemis”, until MONUC reinforcements could take over in September 2003. France set up operation "Black Mamba” and on 5 June the EU adopted a "joint-action on the European Union military operation in the Democratic Republic of Congo". The European Union was already heavily involved in the region through its ECHO (European Commission's Humanitarian Aid Office) humanitarian aid programme and was therefore well placed to carry out such a peacekeeping operation.

France and the UK had already issued a joint declaration to African leaders at La Tourquet in February for more human rights, democracy, conflict prevention and peace in Africa. France, historically the most aggressive advocate for separate EU military capability, [8] wanted to show only two months after Operation Iraqi Freedom that the EU could independently act without NATO using its military capabilities and cooperation, and thus act as a counterweight to the US. France attempted to gain additional military and diplomatic support from other states. Artemis, as the first autonomous EU-led operation, outside Europe, would also emphasize the EU's ambitions for a stronger voice in security affairs. [10]

The current situation in many African states provides a breeding ground for terrorism and extremism. Without good governance and adequate security forces or intelligence, extremist groups and factions are free to create and expand their networks and develop into terrorist cells. [9] One such example is the al-Qa'ida attack in Mombasa, Kenya, in November 2002, which claimed 13 lives, whilst there is concern that numerous al-Qa'ida cells may be developing or operating in "troubled African states", and therefore provide threats to the future of European security. [11]

According to Duke [12] France's willingess to assume the bulk of the burdens in an operation involving a modest number of personnel and resources and with a limited time frame helped other EU states to join. The operation (codename “Artemis”) was then organized under French command and composed of 1,850 troops from 9 countries, mainly France.

France, which provided 1,500 of these troops with main air strike capabilities, and Sweden (approx. 80) were the only participants who provided combat troops in Bunia. For the operational structure of forces see next figure. A French officer, General Jean-Paul Thonier was named "Artemis" force commander, with headquaters in Entebbe (Uganda), while the operational commander was another Frenchman, General Bruno Neveux, who led from his headquarters in Paris. As an initial measure, a nine-man team was deployed on $20^{\text {th }}$ May, 2003, to Bunia to assess the ground conditions and to initiate preparations to secure the airport there 


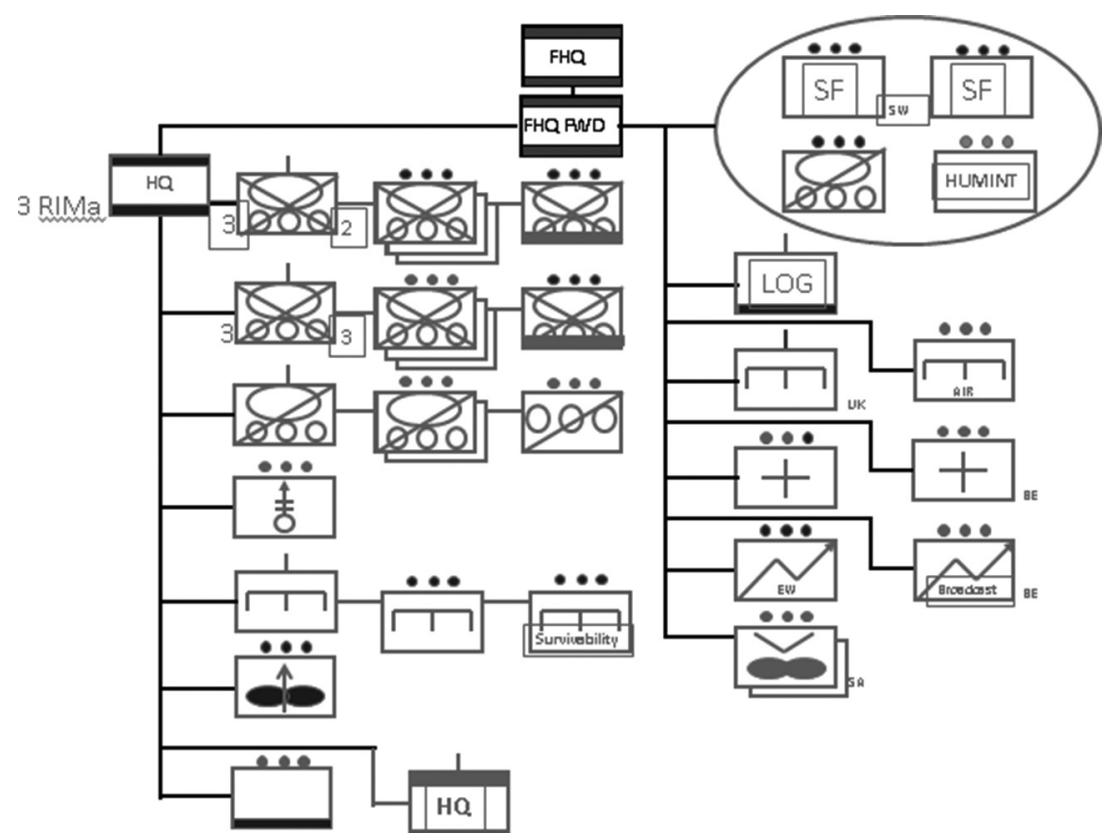

Figure 1. Operational structure of forces. [13]

The UK provided 90 personnel (mainly engineers), and Belgium provided a radio communications center and a field hospital, all in Bunia. Several other European states (Austria, Germany, Greece, Hungary, Ireland, Italy, Luxemburg, The Netherlands, Portugal, and Spain) provided a few personnel for service at the Headquarters in Paris. At its peak, Operation "Artemis" involved the deployment of a total of 2,200 personnel from 17 countries, 12 of them EU member states, and three of them - South Africa, Canada and Brazil - non-European nations.

On $12^{\text {th }}$ June 2003, the Council Decision 2003/432/CFSP launched the military operation of the European Union in the Democratic Republic of Congo.

\section{Mandate}

The mandate was to stabilise Bunia, protect civilians under imminent threat of physical violence, restore the security to the town and the airport, establish a weapons-free zone inside the town and improve humanitarian conditions until September 2003, when the reinforcement of the UN peacekeeping Mission, known as MONUC, was supposed to arrive.

Just under half of the forces were at the force headquarters (FHQ) in Entebbe, Uganda around $300 \mathrm{~km}$ away. The French air force supported the mission with reconnaissance, air support and surveillance from airfields at Ndjamena and Entebbe. The aircraft included some Mirage fighters. MONUC was operating two or three regular flights a day out of the Bunia airport when the first IEMF plane landed. On 6th June, 2003, the first troops of the IEMF were deployed to Bunia. These elements were followed shortly by engineers to help maintain the very poor airfield for the numerous strategic and tactical airlifts of personnel and 
equipment. Each IEMF company had a doctor and a field level unit hospital with surgical capacity in Bunia. In fact, the only real access to Ituri's main town was a small, rough and ready airstrip, accessible only by C-130 Hercules or C-160 Transall tactical transport aircraft.

The following air assets were available:

Air recconossance:

- 1 pc. ATLAS-2 (FR).

Tactical Air-transport:

- 2 pcs. C-130, 1 pc. C 160

FR,

- 2 pcs. C-130

$\mathrm{BE}$,

- 2 pcs. C-130

CA,

- 2 pcs. C-130

UK,

- 2 pcs. C-130

BR.

Fighters:

- 4 pcs. Mirage F1 CR (4 in Entebbe, 8 in N’Djamena as reserve).

Helicopters:

- 2 pcs. Puma, 2 pcs. Gazelle (FR),

- 2 pcs. Oryx (SA).

With regard to reserves, Operation “Artemis” had operational reserves:

- 2 infantry companies in Gabon;

- 1 infantry company in Chad;

- 1 infantry company in Djibouti.

Until to the end of the operation strategic reserves were not offered, hovever it was clear that in case of an emergency France would provide strategic reserves from the "hexagon" (i.e. from France itself).

Meanwhile, the European Commission's Humanitarian Aid and Civil Protection department (ECHO) initiated a clear and informal communication mechanism between Operation "Artemis" and the humanitarian community. These partnerships in the district periphery, emergency stocks and regular ECHO Flight services were part of this operation.

On 6 June 2003, IEMF forces took up position and secured Bunia airfield without any problems. From the start, the operation commander took a firm stance against the militia that were terrorising the local civilian population. General Thonier advised his men to "hit back hard, the first chance you get”. The IEMF used the threat of or the use of force in a convincing manner. It quickly established its presence and stabilized the area of deployment, by limiting itself initially to declaring the town and a $10 \mathrm{~km}$ area around it a "weapons-invisible" zone. This meant that the weapons were carried openly were confiscated, but there was no attempt to disarm militia groups. In fact, weapons disappeared from the streets but were not taken out of circulation. List of collected arms:

- 22 pcs. AK-47 assault rifle,

- 1 pc. PKM machine gun,

- 6 pcs. RPG-7 anti-tank rocket-propelled grenade launcher,

- 1 pc. $107 \mathrm{M} / \mathrm{M}$ antitank gun,

- 2 pcs. $60 \mathrm{M} / \mathrm{M}$ mortar,

- 1 pc. $14.5 \mathrm{M} / \mathrm{M}$ heavy machine gun,

- 120 pcs. handgrenades.

Beyond the town, the rival groups continued to fight and the IEMF was often caught in the middle. 
By the time "Artemis" was properly launched on 12 June, 2003, in the north-eastern Ituri province of the Democratic Republic of Congo (DRC), there had been approximately 430 deaths. The mission's European "strategic" HQ in Paris was fully operational from 16 June. The Europeans retaliated after every provocation or attack by the militias, and on $16^{\text {th }}$ June several militiamen were killed when IEMF forces returned fire.

Some skirmishes started against Lendu forces and the UPC on June $14^{\text {th }}$, in which another twenty militiamen wre killed. Having made it clear to the militias that IEMF forces would use force and by weakening the military capabilities of the militias through monitoring of airfields and cutting off military supplies from abroad, the militias retreated. The European troops gradually secured Bunia and brought an end to the violence and. On 21 June, they forced the 2,500-strong UPC rebels to cede control of the area to Artemis, thereby extending their control to the immediate surroundings of ther town. On 8th July, 2003, Bunia was declared "a weapon-free town", and the city was controlled by several checkpoints and patrols. On 11 July, following provocations, 300 European troops moved into the Hema militia camp near Bunia. Heavy weaponry was seized, which made the UPC withdraw from the region.

Meanwhile, on 28 July 2003, the Security Council resolution 1493 [7] approved a significant expansion of MONUC to 10,800 personnel, including the deployment of a brigade to Ituri, composed of four battalions and support elements (4,800 military personnel) to take over from the IEMF and to expand its mandate from Bunia and its environment, as the situation permitted, to other parts of Ituri. In the first half of August, preparations for the withdrawal from Bunia were started, because the IEMF leadership was concerned that the expiration of the authorized mandate by the Security Council would leave the forces without legal cover in the case of any incident occurring. This led the force to accelerate its withdrawal and seek an extension of the authorization by the Security Council until 15 September, 2003.

Due to the success of the IEMF in securing the area, political offices reopened, economic and social activities in Ituri resumed, and delivery of international aid (food, water, medical care, restoration of the eletric power plant etc.) also resumed. The town's population increased from only 40,000 inhabitants in Bunia before “Artemis" to 100,000. The IEMF, which was initially sceptical that the period of deployment was not sufficient to secure the area, did not face significant difficulties. Nevertheless, the IEMF asked the UN SC for an extension until September $7^{\text {th }}$ 2003. From September $1^{\text {st }} 2003$, the IEMF gradually handed over all remaining tasks in Bunia in a well-planned and well-executed manner to the 5,000-strong MONUC-force from India, Pakistan, Bangladesh, Nepal and Indonesia and withdrew completely by 7 September, 2003. On 25 September, 2003, the support base in Entebe, Uganda ceased to function.

Following the rapid deployment of about 1,800 troops to the region in June 2003, Bunia was secured but massacres continued in the countryside. By December 2003 one of the major waring parties in the region, the Union of Congolese Patriots (UPC) had split and fighting in the region decreased significantly. Finally, the regional dynamic of the conflict in Ituri remains unresolved. It is unclear how Uganda and Rwanda will react to the dismantling of their proxy forces in Ituri district. Although Uganda's direct involvement in the region has been heavily scaled down since the withdrawal of its troops in April 2003, the UN panel on the arms embargo in the eastern DRC has documented its continued involvement in the plundering of the district's resources. Although Rwanda's involvement in the province was never as intense as that of Uganda, it had and may still have close links to UPC factions. 


\section{Evaluation}

Operation "Artemis" was the first independent EU mission outside NATO, where its troops engaged in combat and through successful military-civilian cooperation. [4] EU diplomacy effectively obtained cooperation of neighbouring states prior to the deployment of the IEMF. The fact that Operation "Artemis" was also present in Uganda sent a positive message to Uganda as key player in improving cooperation. In fact, the EU is thus acquiring greater credibility on the international stage and affirming its role as a political and military player in the settlement of international crises and conflicts, because the EU showed its ability to act toward a common foreign security policy to promote regional stability by helping to develop a safer world and carry out all the tasks set out in UN Security Council Resolution 1484. Dr Havier Solana himself referred to “EU military progress”, due to its ability to secure Bunia’s airport, and to assist and protect the displaced persons located in the surrounding refugee camps. It also allowed humanitarian assistance like the World Food Programme to get aid through to the local population and the refugees by restoring the security conditions necessary for NGOs and - through putting an end to the immediate crisis - ensured a return to normal working life, so that many people that had left moved back.

Furthermore, it helped MONUC to build onto the safe foundations laid by Operation “Artemis”. On one hand Operation "Artemis” was a big humanitarian, military and political success by restoring security, helping people to return home and restarting economic activity.

However, the success was partly due to the fact that the mission was narrowly defined (limited time frame and space) and due to the highly-skilled, flexible and well trained troops, which illustrates that missions require adequately trained, equipped and supported reserve forces, who are highly mobile and ready to be deployed rapidly in unpredictable environments. It is also clear that there were also shortcomings of the Union's real capabilities and areas in which these were lacking. The highly multi-nationalised tactical and strategic airlift operated flawlessly, but the overreliance on the Franco-German built C-160-Transall carrier aircraft for long distances illustrated the shortcomings of the European armed forces in terms of strategic lift capability. The limitations of this aircraft in terms of mass and lift capacity make the required number of sorties high. This explains why a more rapid build-up of "Artemis" forces on the ground was not possible, and this was also a reason why the EU rented Antonov 124 transport airplanes.

Indeed, the strict limitation in terms of time and area of operations merely pushed the problem of violent aggression against civilians beyond the environs of the town, where atrocities continued. In this regard, the IEMF acted intelligently, because it understood that its own security depended on securing the surrounding area.

However, it has to be acknowledged that Operations “Artemis” was just the beginning of ESDP involvement in the DRC and limited in time (three months), resources (1,850 troops) and a distant destination (6,000 km from Europe) but in limited Area of Operation (Bunia). We have to confirm that the reason why France, in particular, was eager to lead this mission was to illustrate the independence and capability of the EU as an international actor and counterweight to the US shortly after the Iraq War.

Operation “Artemis" also underlines the fact that international actors can cooperate effectivly in the framework of international law. Although the realists may have a point in arguing 
that security (breeding ground for terrorism) was here a main issue for the involvement of mainly European countries, the participating nations understood that they needed to support each other in a framework of a "division of labour" concerning costs- and task-sharing. This may have also been the reason other UN Security Council members supported the task-sharing, especially the US, which was rather desperately seeking allies already in the Iraq War in 2003, in order to share burdens.

The French command of “Artemis” placed a civilian-military liaison officer on the ground immediately, along with the first French troops that arrived in Bunia. His role was to liaison with those providing humanitarian assistance in Bunia and the region, which went very successfully. CIMIC projects launched in BUNIA: [13]

Eletric power station repair at BUDANA: 80,000 EUR

Save the Children project:

25,000 EUR

Local football stadium repair:

5,000 EUR

Water system repair:

2 bridges built:

15,000 EUR

15,000 EUR

\section{Conclusion}

The Genocide of Tutsis in Rwanda resulted in an involvement of Rwandan and Ugandan troops in Congo in two Congo wars. Despite peace agreement between the involved actors, violence continued until diplomatic intervention by the United Nations led to an agreement for withdrawal of Ugandan and Rwandan troops from Congo. This, however, caused a political vacuum in the Ituri region and its capital Bunia. The United Nations peacekeepers of MONUC were under-resourced and their mandate was too limited in Ituri to deal with the ensuing violence and the inability of humanitarian organizations to provide their services after the withdrawal of Ugandan troops. In order to stop the violence between ethnic militias, the United Nations Security Council authorized in Resolution 1484 the mandate for the multinational Operation “Artemis” under the leadership of France, which included primarily EU countries, to protect civilians and UN staff and re-enable humanitarian assistance in Bunia through securing both the city and the airport of Bunia.

This paper had the intention to argue that Operation "Artemis” was a solution for the Congo Conflict from the EU's perspective, and it was a real test of the EU's crisis management capacity. Moreover, the operation significantly helped the EU to accomplish the Headline Goals 2003 and 2010.

On June $12^{\text {th }}$, the first EU troops landed in Bunia to take control and gradually extended their zone of influence. By implementing "weapon-free” zones in and around Bunia and hitting-back hard against any attacks, IEMF forces successfully re-established normal activities and a return of civilians to Bunia and the surrounding areas, while forcingthe ethnic militias to withdraw.

At the end of the Mandate, the IEMF had successfully completed its task and between September $1^{\text {st }}$ and September $7^{\text {th }}$ handed over effective control of Bunia partially to the expanded MONUC forces. This success was the result of the uncompromising attitude and coordination and adequate equipment of the IEMF forces. The EU and France in particular were very keen on illustrating the independence and ability of the EU as an international actor in international security matters, especially in the wake of the illegitimate Iraq war by a 
US-led coalition. However, pre-deployment liaison with other agencies, including the United Nations, a more generous time and space framework (limited to Bunia and surroundings) and more continuity of EU policy in Africa (no EU intervention since 2003 despite continuing conflicts and genocides) would be more advantageous. Nevertheless, Operation "Artemis" illustrates that the EU has the capabilities to successfully execute mandates, if the EU member states are willing and agree upon foreign policy actions.

Subsequently Operation “Artemis” with its operational dimension (limited space, maximum 3 months of duration, maximum 2,000 troops) has become a modell for the EU's battle group concept. This mission has shown the increasing importance of international cooperation in the field of crisis management.

Finally yet importantly, the EU is doubtlessly improving its capabilities in order to become a more coherent global actor. For years, the EU has been criticized for not having military means, and now under the framework ESDP the EU is trying to develop its military capabilities as well as its civilian means. Operation “Artemis” was a test to see whether the EU was capable of launching such an operation, directing and concluding it on its own, or not. Although there is a great deal of room for improvement, Operation "Artemis" was an encouraging first step towards a better institutional order inside the Union for developing the crisis management capabilities and a more coherent discourse for becoming a global actor.

\section{References}

[1] BESENYŐ J., GYARMAZ Á, HETÉNYI S. Á, PETŐ G., SZÍJJ D., RESPERGER I.: Országismertető - Kongói Demokratikus Köztársaság. Székesfehérvár: MH Összhaderőnemi Parancsnokság, 2010. www.kalasnyikov.hu/dokumentumok/ orszagismerteto_kongo.pdf (downloaded: 3112 2014)

[2] BORDAS M.: A hatékony állam és a jogállam konfliktusa? Közjogi Szemle, 43 (2011), 16-17.

[3] BAVIER, J.: Congo war-driven crisis kills 45,000 a month: study. Reuters, Jan 22, 2008. www.reuters.com/article/2008/01/22/us-congo-democratic-death-idUSL2280201220080122 (downloaded: 3112 2014)

[4] BORDAS M.: Tradition and Modernization in the Public Administration - Efficient State or State under the Rule of Law. Journal of US-China Public Administration, 9680 (2012), 602-603. www.davidpublishing.com (downloaded: 3112 2014)

[5] HENDRICKSON, R.C. et al.: Operation Artemis and Javier Solana: EU Prospects for a Stronger Common Foreign and Security Policy. www.journal.dnd.ca/vo8/no1/hendrick-eng. asp (downloaded: 3112 2014)

[6] UN Security Council Resolution 1291. 24 February, 2000. www.un.org/en/peacekeeping/ missions/past/monuc/mandate.shtml (downloaded: 3112 2014)

[7] Security Council Authorizes in Terim Force in Bunia, Democratic Republic Of Congo, until $1^{\text {th }}$ September. UN SC Press Release, 4764 ${ }^{\text {th }}$ Meeting, 30 May 2003. www.un.org/press/ en/2003/sc7772.doc.htm (downloaded: 3112 2014)

[8] BESENYŐ J., HETÉNYI S. A.: A francia Afrika-politika változása. Seregszemle, IX 3-4 (2011), 199-208. www.scribd.com/doc/126276223/Sereg-Szemle-IX-evfolyam-3-4-szam2011-oktober-december-199-207-oldal (downloaded: 3112 2014) 
TOMOLYA János: Operation “Artemis”: The First Autonomous EU-led Operation

[9] BORDAS M.: Problems of State Efficiency and Terrorism in North Africa. Journal of USChina Public Administration, 122 (2015), 53-68. www.davidpublishing.com (downloaded: 3112 2014)

[10] Commission of the European Communities (CEU): Report on responses to crises - DRC, Pakistan, Lebanon and Burma/Myanmar. 2007. http://ec.europa.eu/echo/files/policies/ consensus/communication_en.pdf (downloaded: 3112 2014)

[11] BORDÁS M.: Arab tavasz vagy iszlám tél? A közel-keleti és észak-afrikai események hatása Európa biztonságára. Honvédségi Szemle, CXVIII. 1 (2015), 56-58.

[12] DUKE, S.: Consensus building in ESDP: The lessons of Operation Artemis. 2008. www.ucd.ie/dei/wp/WP_08-7_Simon_Duke.pdf (downloaded: 3112 2014)

[13] TOMOLYA, J.: 99 nap az ARTEMIS-ben. Szárazföldi Haderő, I 3 (2004) 26-28. 